У УК 659.1:316.772.5:004.738.5

DOI: 10.26565/2218-2470-2021-11-06

ם

口

К КОМУНІКАТИВНІ ІНДИКАТОРИ КОНТЕКСТНОЇ РЕКЛАМИ У СИСТЕМІ ЦИФРОВОГО МАРКЕТИНГУ Зінюк Анна Володимирівна - кандидат соціологічних наук, доцент кафедри
прикладної соціології та соціальних комунікацій Харківського національного університету - імені В. Н. Каразіна, майдан Свободи, 4, Харків, 61022, Україна, email: anna.zinyuk@karazin.ua, ORCID ID https://orcid.org/0000-0002-0369-8892.

- Каторов Денис Олександрович - фахівець 3 інформаційних технологій, інтернет- маркетолог компанії Netpeak, вулиця Коцарська, 2/4, Харків, 61052, Україна, email: - d.katorov@netspeak.net.

- Особливості розвитку комунікативних технологій дають користувачам чималу - свободу. Вони можуть знаходити один і той же товар на різноманітних сайтах, виходити в - мережу використовуючи декілька пристроїв. Тому для успішної та ефективної рекламної компанії уже не достатньо використовувати один канал, одне повідомлення чи один - пристрій. Варто побудувати иілісну систему з джерел трафіку, котра буде складатись 3 - декількох послідовних етапів. В статті розглядається контекстна реклама для пошуковоі - та контекстно-медійної мережі. Реклама в пошуковій мережі слугує для додаткового (допоміжного) або ж кінцевого контакту перед конверсією. Допоміжним вона стає в тому - випадку, якщз ичикл покупки доволі довгий, $і$ клієнт не відразу приймає рішення, про покупку. - Остаточним - якщо ичикл покупки короткий, або користувач знаходиться на останньому - етапі иьього ичклу. Для того, щуоб повернути аудиторію на свій сайт варто використовувати - ремаркетинг. Технологія дозволяє демонструвати оголошення тим користувачам, котрі - уже відвідували сайт. Таким чином, ремаркетинг стає останнім каналом перед здійсненням - конверсіі. Авторами акцентовано увагу на тому, щзо оптимізувати багатоканальну - атрибуцію можливо через ключові індикатори комунікативної ефективності: залучення, - взаємодію та конверсію. До основних індикаторів залучення відносять показники, котрі свідчать про ставлення користувача до реклами (показник якості оголошення, покази та - перегляди, кліки). Індикатори взаємодї вказують, як користувач поводив себе на сайті після - переходу по рекламному оголошенню (час проведений на сайті, показник виходів та глибина - перегляду сайту). Останній рівень індикаторів має найбільшу цінність, тому щуо він вказує на пряму ефективність рекламного оголошення, котра в основному виражена у фінансовому еквіваленті (витрати на клієнта і рентабельність інвестицій).

Ключові слова: контекстна реклама, комунікативні індикатори, ремаркетинг, - пошукові системи, показник ефективності, цифровий маркетинг.

() Зінюк А. В., Каторов Д. О., 2021 


\section{COMMUNICATIVE INDICATORS OF CONTEXT ADVERTISING IN THE DIGITAL MARKETING SYSTEM}

Zinyuk Anna - PhD in Sociological Science, Associate Professor, Associate Professor of Sociology of Applied Sociology and Social Communications Department of V. N. Karazin Kharkiv National University, 4, Svobody Sq., Kharkiv, 61022, Ukraine, email: anna.zinyuk@karazin.ua, ORCID ID https://orcid.org/0000-0002-0369-8892.

Katorov Denis - information technology specialist, Internet marketer of Netpeak, 2/4, Kotsarska Street, Kharkiv, 61052, Ukraine, email: d.katorov@ netspeak.net.

Features of the development of communication technologies give users considerable freedom. They can find the same product on different sites, go online using multiple devices. Therefore, it is no longer enough to use one channel, one message or one device for a successful and effective advertising campaign. It is necessary to build a holistic system of traffic sources, which will consist of several successive stages. The article discusses contextual advertising for the search and content network. Search advertising is used for additional (auxiliary) or final contact before conversion. It becomes ancillary if the purchase cycle is quite long, and the customer does not immediately make a purchase decision. Final - if the purchase cycle is short, or the user is in the last stage of this cycle. Remarketing should be used to get your audience back to your site. The technology allows you to show ads to users who have already visited the site. Thus, remarketing becomes the last channel before the conversion. The authors emphasize that it is possible to optimize multichannel attribution through key indicators of communicative efficiency: involvement, interaction and conversion. The main indicators of engagement are indicators that indicate the user's attitude to advertising (indicator of ad quality, impressions and views, clicks). Interaction indicators indicate how the user behaved on the site after going to the ad (time spent on the site, the rate of output and depth of viewing the site). The last level of indicators has the greatest value, because it indicates the direct effectiveness of advertising, which is mainly expressed in financial equivalent (customer costs and return on investment).

Keywords: contextual advertising, communicative indicators, remarketing, search engines, performance indicators, digital marketing.

Сьогодні з'являються нові канали, способи та майданчики для реклами товарів та послуг в Інтернеті. Можна спостерігати тенденцію багатоканальності у цифровому просторі. Це ситуація, в котрій користувач перед тим, як виконати цільову дію повинен декілька разів контактувати 3 рекламним повідомленням. Виходячи 3 цього, рекламодавцю уже не достатньо запустити рекламу лише через один канал. Він повинен враховувати різноманітні рекламні канали та пристрої. I лише після цього приступати до створення рекламної продукції.

Щодня мільйони користувачів в усьому світі вводять свої запити в пошукових сервісах, шукаючи інформацію про товар. Також, пошукові системи співпрацюють 3 мільйонами сайтів, котрі охоплюють 90\% вебпростору. Щоб отримувати прибуток з таких значних масивів даних, пошукові сервіси використовують контекстну рекламу. Це робить контекстну рекламу одним з найпопулярніших інструментів для рекламодавців у цифровому маркетингу.

Контекстна реклама розміщується в пошуковій та контекстно-медійній мережі. Може мати форму текстового оголошення, графічного банера, відеореклами, рекламні оголошення 
в мобільних додатках, та інші форми реклами. Однак, не достатньо просто створити різні повідомлення для користувачів. Окрім цього, варто, щоб вони працювали в певній системі, яку можна розкласти на послідовні етапи. А кожен етап повинен містити в собі певні індикатори, які демонструють його успішність. Якщо проігнорувати це, тобто використовувати лише один канал, одне повідомлення, то висока імовірність провалу рекламної кампанії у цифровому середовищі.

Дослідженням проблеми багатоканальності в цифровому маркетингу займаються такі вчені як: А. Воронюк, Д. Савельєв, А. Липський, Д. Лазарєв, А. Бабаєв, Н. Свдокімов, А. Іванов, Ю. Склахов, Д. Бараксанов, І. Абдулов, Л. Одден, М. Джеффрі, С. Годін та інші. Дослідженням, ролі контекстної реклами в цифровому маркетингові займались такі вчені як: А. Кошик, Т. Еш, Б. Геддс, М. Уваров, К. Живенков, П. Маршалл, Б. Тодд, Б. Кліфтон, И. Манн, В. Давидов, О. Рудаков, А. Осипов та інші.

Мета даної статmі полягає у визначенні індикаторів комунікативної ефективності контекстної реклами в системі цифрового маркетингу.

Перш за все, варто визначити сам термін контекстна реклама. У глобальному сенсі: «Контекстна реклама - це тип Інтернет-реклами, при якому рекламне повідомлення з'являється відповідно до змісту і контексту Інтернет-сторінки. Контекстна реклама діє вибірково і відображається для відвідувачів тих Інтернет сторінок, сфера інтересів яких потенційно співпадає або перетинається з тематикою реклами товару чи послуги» [8, с. 31].

«Контекстна реклама - це реклама в контексті потреб користувача, що відповідає його інтересам» [1, с. 15]. «Реклама, зміст якої залежить від інтересів користувача. Контекстна реклама діє вибірково: рекламне повідомлення показується тільки тим, хто хоче його побачити. Користувачі виявляють цікавість до тих чи інших товарів і послуг, а ви пропонуєте їм допомогу, розповідаючи про свої пропозиції. Користувач сам докладає зусиль, щоб відшукати рекламне повідомлення» [10].

Інструмент, який допомагає демонструвати рекламні повідомлення не масово, а вибірково, лише тим, хто проявляе найбільший інтерес до товарів. Також можна виявити сегменти з конкретними інтересами, запитами та потребами. Маючи ці данні, рекламодавець створює повідомлення, які б інформували аудиторію де саме (на якому сайті), вона зможе якомога краще задовольнити свої потреби чи розв'язати свої проблеми. Цей інструмент надає переваги, як користувачам (швидко задовольнити свої запити), так і рекламодавцям (показувати рекламу товару чи послуги лише тим, хто в ній реально зацікавлений).

Контекстна реклама надзвичайно популярний інструмент у всіх сферах бізнесу. Розглянемо комунікативні особливості, які обгрунтовують значущість контекстної реклами у сучасному цифровому просторі:

1. Широкий спектр циілей, яких можна досягти за допомогою контекстної реклами: залучити нових відвідувачів на сайт, збільшити кількість онлайн-продажів, отримувати більше дзвінків або заохотити клієнтів до наступних покупок.

2. Надзвичайно легко знаходити необхідну аудиторію. Набір опцій дає змогу націлювати рекламу за типом сайту чи аудиторії, часом і місцем розташування.

3. Оиінювання $i$ звітність. За допомогою статистичних даних Google AdWords або Яндекс Директ (для поглибленого аналізу, можна інтегрувати данні в інструменти аналітики Google Analytics та Яндекс Метрика), можна дізнатись точну кількість людей, які побачили повідомлення рекламодавця та натиснули на них. Також, можна дізнатись, скільки транзакцій отримано з того чи іншого рекламного повідомлення.

4. Гнучкість та мобільність. Інструменти допомагають швидко вмикати, вимикати чи зупиняти оголошення, групи оголошень чи кампанії. 
5. Оптимізація та корегування. Знаючи данні щодо ефективності повідомлень, рекламодавець має можливість регулювати бюджетні ставки для них. Наприклад, для успішних повідомлень, варто підіймати ставку, щоб збільшити охоплення та кількість кліків на рекламу. А от для не ефективної реклами, можна знизити ставку, або взагалі вимкнути його.

6. Детальні налаштування таргетингу. За допомогою контекстної реклами, можна 3 легкістю виділити релевантну аудиторію і показувати повідомлення лише їй.

7. Гнучке медіапланування. Точно обрати найбільш зручний час та місце для розміщення реклами для цільової аудиторії.

8. Плата за результат. Рекламодавець сплачує лише в тому випадку, якщо користувач виконає один із сценаріїв. Тобто, це може бути плата за 1000 показів (для контекстно-медійної мережі). Або плата лише за клік по рекламному повідомленню (для пошукової мережі). Чи, найліпший варіант для рекламодавця, плата за конверсію [6].

Простота налаштувань, охоплення необхідної аудиторії, низька вартість - усе це зробило контекстну рекламу життєво необхідним інструментом, для всіх, хто пов'язаний 3 цифровими комунікаціями.

Перш за все, варто сказати, що технологія контекстної реклами залежить від того, до якої пошукової системи вона належить. Так, можна виділити декілька найбільш відомих міжнародних пошукових систем - Goggle, Yahoo, Bing та інші. Також, існують пошукові системи, які користуються популярністю в окремих регіонах. Наприклад, Яндекс для Інтернет-простору СНД, або ж Ваidu для азійських країн.

Перед початком налаштування та запуском компанії, варто зрозуміти ключову комунікативну ціль рекламної кампанії. У глобальному сенсі визначення подібної цілі. «Комунікативна ціль - створення і підтримування постійних зв'язків між фірмою і ринком 3 метою активізації продажу товарів і формування позитивного іміджу иляхом інформування, переконання та нагадування про свою діяльність» [9].

Дана концепція має зв'язок з мікро та макроконверсіями. Щоб конверсійна воронка працювала максимально ефективно, варто інформувати, переконувати та нагадувати (мікроконверсія) про себе, з метою продажів (макроконверсія).

Для того, щоб зрозуміти, який саме тип кампанії обрати (з урахуванням багатоканальних послідовностей та асоційованих конверсій), використаємо модель циклу покупки. Так, більшість дослідників сходяться в думці, що людина проходить стадії при виборі товару - час до покупки, під час покупки і після покупки [2, с. 147-291].

1. До покупки. Користувач замислюється про певну потребу чи товар, або тільки починає шукати інформацію про певний товар. У першому випадку, варто використовувати КММ. Тобто, використовувати банери, графіку, зображення, відеоконтент. Це необхідно, щоб користувач відвідав сайт чи певну сторінку, яка б інформувала про товар чи послугу.

У другому випадку, можна використовувати як КММ, так і пошукову мережу. Адже, на цьому етапі користувач знає, що в нього існує певна потреба. Проте, він може не знати, як саме їі задовольнити. У подібній ситуації, варто орієнтуватись на ключові слова, які цільова аудиторія вводить у пошукових системах. Однак, у цій ситуації, не варто давати рекламу про конкретний товар. Краще приводити користувачів на блоги чи статті, де аудиторія зможе ознайомитись з інформацією про переваги конкретних товарів. Після цього, споживач матиме чітке уявлення про те, який товар йому необхідний.

2. Покупка. На даному етапі людина усвідомлює свої потреби, та приблизно знає, який саме товар їй необхідний. 3 точки зору контекстної реклами, знову ж таки, маємо справу 3 двома ситуаціями. Якщо користувач не заходив на сайт, то рекламодавець використовує 
лише пошукову мережу, та конкретні ключові слова, які будуть вести аудиторію на релевантну сторінку.

Якщо ж користувач відвідував сайт, то рекламодавець використовує технології ремаркетингу. «Ремаркетинг - технологічна функція, яка дозволяє звернутись до користувачів, котрі раніше відвідували сайт. Це означає, що рекламні повідомлення будуть з'являтись для релевантної аудиторії» [4]. Використовувати загальний ремаркетинг (якщо споживач відвідав лише головну сторінку), або технологію динамічного ремаркетингу (якщо користувач, відвідав сторінку з певним продуктом). Ремаркетинг спрямований на те, щоб користувач повернувся на сайт, і здійснив остаточну транзакцію.

3. Після покупки. 3 точки зору Інтернет-маркетингу, нових користувачів стає усе менше, зростає рівень конкуренції в усіх сферах бізнесу, і тому варто утримувати покупців. 3 цією метою, знову ж таки використовується технологія ремаркетингу. Але тепер, вона виконує дещо іншу функцію.

Якщо на другому етапі, існувала мета продати товар, то тепер основна мета продати товари, які можуть йти в комплекті з проданим раніше продуктом. Безумовно, подібна увага 3 боку Інтернет-магазинів, може не подобатись ряду користувачів. Проте, через зростання конкуренції та зменшення споживачів, доводиться використовувати подібні технології. 3 іншої сторони, споживач який придбає товар декілька разів підряд у певному магазині, буде проявляти більше лояльності як до самої мережі, так і до іiі реклами.

Якщо розглядати контекстну рекламу з такої точки зору, то стає легше зрозуміти, як саме використовувати цей інструмент.

Таким чином, розглянемо три типи комунікативних індикаторів контекстної реклами залучення, взаємодія та конверсія. Перші два показники, пов'язані з медіа індикаторами. Конверсія - в переважній більшості для контекстної реклами, стосуються фінансових та економічних показників. Також, чітко відстежується ієрархія індикаторів. Зважаючи на той факт, що рекламодавець повинен робити релевантні рекламні оголошення, то зміна показників на одному рівні, призводить до змін на усіх інших.

Далі, зупинимось на загальних показниках, котрі притаманні кожному інструменту контекстної реклами, а також розглянемо індикатори, котрі зустрічаються лише в конкретному інструменті.

1. Поверхневий рівень, пов'язаний з загальним залученням користувачів:

Показник показів. Скільки взагалі людей побачили оголошення. Даний параметр зустрічається в усіх типах кампаній. Показ зараховується в тому випадку, якщо оголошення 3'являється в пошуковій мережі чи на сайтах партнерів. Також, можна демонструвати рекламне повідомлення цільовій аудиторії певну кількість разів. Наприклад, знаючи, що для конверсій достатньо сім показів рекламного повідомлення для конкретного користувача, рекламодавець може встановити саме таку частоту показів [3].

Показник кліків. Дозволяє дізнатись наскільки рекламне повідомлення привабливе для користувачів. Чим більше кліків отримано, тим цікавіше рекламне повідомлення [7]. Проте, варто бути обережним - багато кліків свідчать про багатообіцяюче оголошення, однак багато переходів не завжди є показником успішної рекламної кампанії. Так, рекламодавець може отримати безліч переходів та кліків, проте більш вагомі показники конверсії не будуть зростати, а показник відмов може зрости. Це свідчить про те, що рекламодавець створив рекламне оголошення, котре зачіпає надто широку аудиторію.

2. Наступний рівень, показник взаємодії. Вказує на те, наскільки рекламне повідомлення виправдало очікування користувачів. Так, сюди входять час проведений на сайті, показник виходів та глибина перегляду сайту. 
Також, для відеореклами та реклами мобільних додатків, використовують альтернативні або додаткові цілі. Так, для відеореклами для рекламодавця важливо, чи подобається відеоматеріал аудиторії (дізнатись про це можна за допомогою кнопки «подобається»), а також, наскільки часто споживачі підписуються на відео канал рекламодавця. Ці характеристики свідчать про високу лояльність аудиторії, і готовність до здійснення цільової дії.

Що стосується реклами для мобільних пристроїв, то оцінюємо іiі взаємодію 3 мобільним додатком або телефонні виклики, які отримали з рекламного оголошення: завантаження додатку - це конверсії, які реєструються, коли користувач уперше завантажує чи встановлює додаток; дії в додатку - це конверсії, які реєструються, коли користувач виконує певну дію в додатку; відстеження викликів - це конверсії, які реєструються, коли користувач зателефонував у компанію через рекламне оголошення [5].

3. Останній рівень, який вказує на конкретну ефективність рекламної кампанії, найчастіше виражену у фінансовому еквіваленті. Всі ці показники, так чи інакше, пов'язані 3 конверсією сайту. Показники можна розділити на дві частини затрати на клієнта i рентабельність інвестицій.

За допомогою цих показників рекламодавець оптимізує та покращує рекламну кампанію. Вони допоможуть зробити рекламні повідомлення більш ефективними.

Правильне розуміння показників та їхньої оцінки, дозволяє правильно інтерпретувати результати рекламної кампанії, а отже покращувати іiі ефективність. Також, це дозволяє висувати не просто гіпотези, а розуміти конкретні причини падіння трафіку на тому чи іншому етапі.

Таким чином, для ефективної роботи інструменту, варто чітко знати як функціонує кожен тип. Тобто, знати ціль та мету інструменту, розуміти правильні налаштування таргетингу, знати як функціонує рейтинг оголошень, розбиратись у бюджетах, сегментувати групи оголошень, знати оператори для ключових слів, створювати релевантні для цільової аудиторії оголошення.

Лише, коли існує розуміння кожного окремого інструменту контекстної реклами, можна переходити до побудови багатоканальних атрибуцій. Так, оголошення з контекстномедійної мережі краще використовувати на старті рекламної кампанії; повідомлення для пошукової мережі підходять в якості додаткового або ж конверсійного каналу; відеорекламу також враховувати в якості першого або додаткового каналу; ремаркетинг використовується в якості передостаннього каналу або ж останнього конверсійного каналу. Хоч це і не остаточна кваліфікація (для деяких типів бізнесу вона може відрізнятись), однак в більшості випадків, можна спостерігати саме таку конверсійну воронку для контекстної реклами.

Також, для ефективного управління кожним етапом, варто розуміти основні індикатори комунікативної ефективності. Умовно, їх можна розділити на три частини спрямовані на залученість, взаємодію та конверсію. Для досягнення поставлених цілей, варто працювати з кожним індикатором.

\section{Література:}

1. Бабаев А. Контекстная реклама : учеб. / А. Бабаев, Н. Евдокимов, А. Иванов. Санкт-Петербург : Питер. 2011. 304 с.

2. Блэкуэлл Р. Поведение потребителей / Р. Блэкуэлл, П. Минирад, Дж. Энджел. / пер. с англ. Санкт-Петербург : Питер. 2007. 944 с.

3. Довідковий центр Google AdWords. Обмеження частоти показів. URL: https://support.google.com/google-ads/answer/117579?hl=uk (дата звернення 12.02.2021). 
4. Довідковий центр Google AdWords. Про ремаркетинг. URL: https://support.google.com/google-ads/answer/2453998 (дата звернення 12.02.2021).

5. Довідковий центр Google AdWords. Реклама вашого мобільного додатку. URL: https://support.google.com/google-ads/answer/6247380?hl=uk\&visit_id=637563237739132775336017194\&rd=1 (дата звернення 12.02.2021).

6. Довідковий центр Google Partners. Переваги реклами в Інтернеті за допомогою AdWords. URL: https://support.google.com/googleads/answer/6123875?topic $=3071897 \& \mathrm{ctx}=$ topic $\&$ path $=2799680 \& \mathrm{hl}=\mathrm{uk} \& \quad \mathrm{ga}=2.41483874 .1177930$ $\underline{822.1494513227-712978330.1494509422 \% 20}$ (дата звернення 12.02.2021).

7. Как рассчитать СРC? Какая формула расчета CPC? / Chekroi. URL: https://checkroi.ru/blog/formula-rascheta-cpc (дата звернення 12.02.2021).

8. Маршалл П. Контекстная реклама, которая работает. Библия Google AdWords / П. Маршалл, Б. Тодд. / пер. с англ. Ольги Лобачевой. Москва : Манн, Иванов и Фербер, 2014. $464 \mathrm{c}$.

9. Руководство для малого бизнеса: как дать контекстную рекламу в поиске Google с помощью AdWords. Netpeak Blog. URL: https://netpeak.net/ru/blog/rukovodstvo-dlyamalogo-biznesa-kak-dat-kontekstnuyu-reklamu-v-poiske-google-s-pomoshch-yu-adwords (дата звернення 12.02.2021)

10. Яндекс. Помощь. Что такое контекстная реклама? URL: https://yandex.ru/support/direct/index.html (дата звернення 12.02.2021).

\section{References:}

1. Babaev, A., Evdokimov, N., Ivanov, A. (2011). Contextual advertising. Textbook. St. Petersburg : Piter.

2. Bljekujell, R. (2007). Consumer behavior. St. Petersburg : Piter.

3. Google AdWords Help Center. Frequency capping. Retrieved from https://support.google.com/google-ads/answer/117579?hl=uk.

4. Google AdWords Help Center. About remarketing. Retrieved from https://support.google.com/google-ads/answer/2453998.

5. Google AdWords Help Center. Advertise your mobile application. Retrieved from https://support.google.com/google-ads/answer/6247380?hl=uk\&visit_id=637563237739132775336017194\&rd=1.

from

6. Google Partners Help Center. The benefits of online advertising with AdWords. Retrieved ads/answer/6123875? topic $=3071897 \&$ ctx $=$ topic $\&$ path $=2799680 \& \mathrm{hl}=\mathrm{uk} \& \quad$ ga $=2.41483874 .1177930$ 822.1494513227-712978330.1494509422\%20.

7. How to calculate CPC? What is the CPC calculation formula? / Chekroi. Retrieved from https://checkroi.ru/blog/formula-rascheta-cpc.

8. Marshall, P. (2014). Contextual advertising that works. Google AdWords Bible. Moscow: Mann, Ivanov and Ferber.

9. A guide for small businesses: how to give contextual advertising in Google search using AdWords. Netpeak Blog. Retrieved from https://netpeak.net/ru/blog/rukovodstvo-dlya-malogobiznesa-kak-dat-kontekstnuyu-reklamu-v-poiske-google-s-pomoshch-yu-adwords/.

10. Yandex. Help. What is contextual advertising? Retrieved from https://yandex.ru/support/direct/index.html. 